\title{
ANALYSIS OF THINNING OPERATIONS IN CORSICAN PINE ARTIFICIAL HIGH FORESTS IN CALABRIA (ITALY)
}

\author{
Giuseppe Zimbalatti, Bruno Bernardi, Stefano Morabito
}

\section{Introduction}

Calabria's considerable forest resources still show signs of their past use, often characterised by occasionally unregulated large-scale interventions which have not only resulted in a reduction of forest area but have above all had damaging effects on the composition and structure of the forests [10].

It is necessary, therefore, to facilitate a renewed dynamic and rational management of forests in order to guarantee an overall improvement in terms of structure and function. Among the decisive aspects emerges the need to carry out forest management which instead due to the high costs are disregarded virtually everywhere $[6,8]$.

The present experimental research derives from this contest, observing operations carried out during thinning of a Corsican pine high forest (Pinus nigra Arn., var. calabrica ssp. Laricio P.), an indigenous conifer widely used in reforesting programmes carried out in Calabria during the period 1958-1978.

In these reforesting programmes, following the planting phase, the essential management stage, including medium and long term forestry interventions aimed at encouraging the ecological and structural evolution of the forests, was generally absent.

With regard to this it needs to be said that the carrying out of specific management interventions such as thinning has the aim of guaranteeing greater efficiency of these artificial plantation, supporting them towards an autonomous increase of their complexity and biodiversity, in order to guide them towards "renaturalization".

Furthermore, the recourse to different levels of intervention has the aim of highlighting those that may

Paper received 25.07.2007; accepted 12.05.2008

Prof. Giuseppe Zimbalatti, Professore Straordinario; Dr. Bruno Bernardi, Dottorando di Ricerca; Dr. Stefano Morabito, Dottore di Ricerca; Dipartimento STAfA, Università Mediterranea di Reggio Calabria.

The authors have contributed equally to the present work. lead to modifying actions able to induce prompter and more significant reactions in the population, in the absence of sufficient experimental examinations on the "intensity" or most suitable level of thinning to encourage re-naturalization [7].

The present work, set against the background that the carrying out of these silvicultural operations contribute towards the development of Calabrian forest systems, has the objective of demonstrating the validity of mechanized interventions, even starting from a rather low initial level such as that of the yard subject of the research; only in this way it's possible open the way for more innovative mechanized systems which could prove decisive in relaunching forestry in gener$\mathrm{al}$ and that in Calabria in particular.

\section{Materials and methods}

The forest considered in the present work is a Corsican pine high forest with trees of the same age, approximately 30 years, originating from artificial reforestation located in the municipality of Bova (RC), at an altitude of $1,200 \mathrm{~m}$ a.s.l..

The area of research covered 0.72 ha with S-E exposition; the forest land is classified as I class for roughness, while the slope is between I class and III $(0 \div 60 \%)[9]$.

The density of the population is generally uniform; small gaps are present only in the areas with lower soil depth. The dense arboreal canopy prevents development of the shrubby undergrowth and in many areas impedes also the forming of a herbaceous layer; a significant presence of fern (Pteridium aquilinum) was noticed, indicating the serious degradation of the soil, doubtless due to the frequent fires the area is subjected to. Renewal is extremely limited and only in the most open areas is it possible to notice the introduction of the fir and holm oak; the phytosanitary conditions are good since there was no evidence of pathogenic attacks.

The area has a good main road network and is flanked by the provincial road; the tracks opened during felling were used as the secondary road network. 


\begin{tabular}{cccc}
\hline $\begin{array}{c}\text { Test } \\
\text { Area }\end{array}$ & Trees & $\begin{array}{c}\text { Mean diameter } \\
\text { at breast height } \\
{[\mathrm{m}]}\end{array}$ & $\begin{array}{c}\text { Mean } \\
\text { height } \\
{[\mathrm{m}]}\end{array}$ \\
\hline $\mathbf{A 1}$ & 211 & 0.260 & 18.9 \\
$\mathbf{A 2}]$ & 190 & 0.275 & 19.4 \\
$\mathbf{A 3}$ & 158 & 0.285 & 19.5 \\
$\mathbf{B 1}$ & 189 & 0.270 & 19.5 \\
$\mathbf{B 2}$ & 158 & 0.265 & 19.9 \\
$\mathbf{B 3}$ & 148 & 0.290 & 19.9 \\
\hline
\end{tabular}

TABLE 1 - Main characteristics of the sampling areas.

From an operative aspect the research area was divided into two random blocks, $\mathrm{A}$ and $\mathrm{B}$, both covering an area of 3,600 $\mathrm{m}^{2}$, occupying opposite slopes. Each block contained three rectangular sampling areas measuring $40 \mathrm{~m}$ x $30 \mathrm{~m}\left(1,200 \mathrm{~m}^{2}\right)$, separated by a 10 $\mathrm{m}$ strip, indicated with the numbers 1-3.

Before utilization, total enumeration of trees in each test area was carried out to record the number, mean diameter at breast height (b.h.d.) and mean height (table 1).

Table 2 also schematically shows dendrometric data in areas where tests were carried out. The basal area is calculated according to the following formulation [11]:

$$
G=\frac{I I}{4} \cdot\left(n_{1} d_{1}^{2}+n_{2} d_{2}^{2}+\ldots+N_{n} d_{n}^{2}\right)
$$

where:

$n=$ number of plants corresponding to each diametric class;

$d=$ diameter at breast height

$[\mathrm{cm}]$

is on average equal to $71 \mathrm{~m}^{2} / \mathrm{ha}$; volume is estimated by using the functional expression [4]:

$$
y=a+b d^{2} h+b y d+b y h+h d h+h d^{2}+b f^{2} h^{2}+b y d^{2} h^{2}+h d^{3}+h d^{2} h^{2}
$$

with:

$$
\begin{aligned}
& a=0.457023 \cdot 10^{-3} ; b_{1}=0.380346 \cdot 10^{-4}: b_{2}=-0.425133 \cdot 10^{-4} \\
& b_{5}=0.160308 \cdot 10^{-2} ; b_{4}=-0.112508 \cdot 10^{-3} ; b_{5}=0.210003-10^{-4} \\
& b_{6}=0.132827-10^{-4}: b_{7}=0.337571-10^{-5}: b_{3}=-0.177836 \cdot 10^{-6} \\
& b_{9}=-0.491192 \cdot 10^{-4} ;
\end{aligned}
$$

$d=$ diameter at breast height

[cm];

$h=$ compensated height

is on average equal to $672 \mathrm{~m}^{3} / \mathrm{ha}$.

During the enumeration phase, trees were marked for felling to carry out a selective thinning, from below, cutting trees that were dominated, withered and those with under-developed crowns.

\begin{tabular}{cccc}
\hline $\begin{array}{c}\text { Test } \\
\text { area }\end{array}$ & $\begin{array}{c}\text { Density } \\
{[\text { trees/ha] }}\end{array}$ & $\begin{array}{c}\text { Basal area } \\
{\left[\mathrm{m}^{2} / \mathrm{ha}\right]}\end{array}$ & $\begin{array}{c}\text { Volume } \\
{\left[\mathrm{m}^{3} / \mathrm{ha}\right]}\end{array}$ \\
\hline $\mathbf{A 1}$ & 1758 & 77.80 & 716.6 \\
$\mathbf{A 2}$ & 1583 & 80.21 & 753.3 \\
$\mathbf{A 3}$ & 1317 & 70.14 & 664.5 \\
$\mathbf{B 1}$ & 1575 & 68.77 & 646.3 \\
$\mathbf{B 2}$ & 1317 & 67.72 & 646.7 \\
$\mathbf{B 3}$ & 1233 & 63.56 & 606.2 \\
\hline
\end{tabular}

TABLE 2 - Dendrometric data of the sampling areas.

Particular attention was given to the degree of thinning adopted, comparing three thesis: control (T), moderate thinning (A), heavy thinning (B).

$32.1 \%$ and $29.7 \%$ of trees were felled in sampling areas $\mathrm{A} 2$ and $\mathrm{B} 3$ respectively (thesis $\mathrm{A}$ ), $48.7 \%$ and $45.6 \%$ in sampling areas A3 and B2 (thesis B); in sampling areas A1 and B1 no intervention was planned regarding the control function (table 3 ).

The choice of the type of thinning carried out had the aim of guaranteeing:

- increased adaptability of artificial populations of Corsican pine, with individuation of those trees with the best morphological characteristics;

- an improvement in the mechanisms of natural growth processes to the advantage of large trees;

- the obtaining of part of the ligneous products before the end of the growth cycle;

- the creation within the forest of pedo-climatic conditions favourable towards the renaturalization with indigenous species.

The work system adopted is the short wood system (Short Wood System - S.W.S.) [9].

\begin{tabular}{cccc}
\hline $\begin{array}{c}\text { Test } \\
\text { area }\end{array}$ & $\begin{array}{c}\text { Trees } \\
{[\mathrm{n}]}\end{array}$ & $\begin{array}{c}\text { Basal area } \\
{\left[\mathrm{m}^{2}\right]}\end{array}$ & $\begin{array}{c}\text { Volume } \\
{\left[\mathrm{m}^{3}\right]}\end{array}$ \\
\hline $\mathbf{A 2}$ & 61 & 1.61 & 13.9 \\
$\mathbf{A 3}$ & 77 & 2.07 & 18.5 \\
$\mathbf{B 2}$ & 72 & 2.25 & 17.7 \\
$\mathbf{B 3}$ & 44 & 1.03 & 6.5 \\
\hline Total & 254 & 6.96 & 56.6 \\
\hline
\end{tabular}

TABLE 3 - Number of trees felled and extent of intervention implemented.

Felling and processing operations were carried out using a medium-sized Jonsered Turbo 2055 chainsaw with cylinder capacity of $53.2 \mathrm{~cm}^{3}$. The two-man work team consisted of a chainsaw operator and a helper with the task of keeping the work area clear 
and helping with felling and processing (delimbing of felled trees, cutting to length). The assortments were arranged as follows: logs $2.05 \mathrm{~m}$ long with a minimum diameter of $0.20 \mathrm{~m}$ destined for the production of packing material and pallets; logs $2.30 \mathrm{~m}$ long with a maximum diameter of $0.20 \mathrm{~m}$ destined for the paper mill. Extraction of the processed material was carried out using a tracked tractor (Massey-Ferguson MF 200) equipped with a modified bucket, useful for burden logging.

Two $0.80 \mathrm{~m}$ long metal bars were inserted into the front part of the bucket in order to increase the loading capacity. Two more bars were added behind to give further support. With its $44 \mathrm{~kW}$ power, the tracked tractor was particularly useful at moving earth, necessary for opening up trails for hauling. The operation involved the loading, transporting and unloading of wood at landing.

Logging of block A, which involved an average distance equal to approximately $110 \mathrm{~m}$, was carried out by a two-man work team with one worker, in addition to operating the vehicle, entrusted with loading the wood; in block B, with a logging distance of 130 $\mathrm{m}$, the work team consisted of three workers, 1 entrusted with operating the tracked tractor and two loaders.

As a result of biometric differences of the processed timber assortments, the number of logs per load averaged 45 timber destined the for paper mill material and 15 for that destined for packing with volumes of $1.70 \mathrm{~m}^{3}$ and $1.54 \mathrm{~m}^{3}$ respectively.

In the B2 test area, with gradients of up to $60 \%$, ligneous material was previously concentrated, for free sliding, at various points on the boundary of the test area easily accessible for vehicles. This preliminary phase required the use of a two-man team.

The branchwood derived from conversion residues is used differently. Dry branchwood is concentrated at different sites to be burnt in the months when burning is permitted. Green branchwood is converted directly using an hauled chipper (Peruzzo T3) fitted with a 9.6 $\mathrm{kW}$ petrol engine.

This operation, important for forests in that it provides an industrial use for ligneous material that would otherwise have little or no economic value, was carried out by a two-man team. Following this phase, sacks for collecting chips were transported to the landing using the tracked tractor. The entire operation was carried out with a three-man team, one to operate the vehicle and two loaders.

For each utilisation operation the sites used were studied, work times were recorded and work capacity and productivity were calculated in accordance with methodology proposed by Berti et al. [2].

\section{Results and considerations on the mechanical aspects}

From the tests carried out, with reference to felling

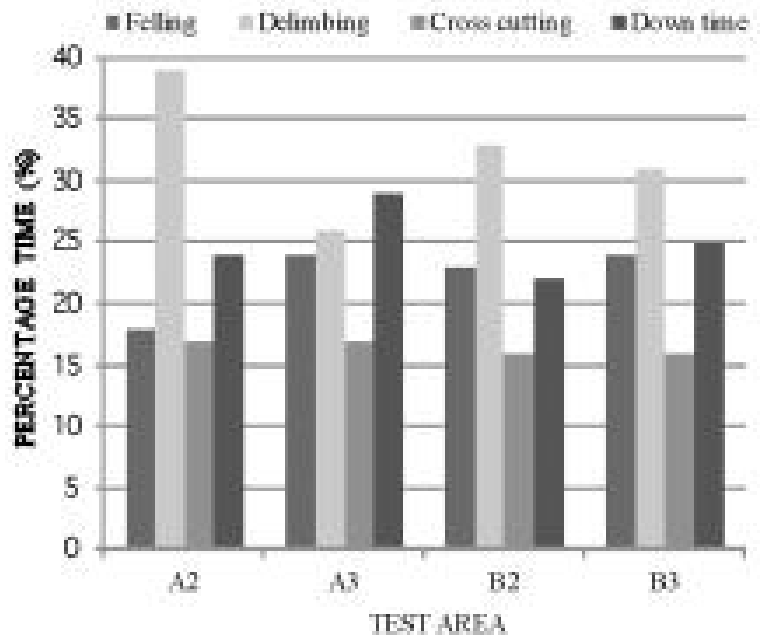

Fig. 1 - Comparison of work times in the four test areas.

and processing operations, a substantial homogeneity emerges among work times recorded in the four test areas studied (figure 1).

Table 4 shows the analysis of total times for felling and processing operations regarding blocks $\mathrm{A}$ and $\mathrm{B}$; the times refer to the work team. Overall the volume of timber felled was $56.6 \mathrm{~m}^{3}$ (table 3 ).

Net time for felling was $4.57 \mathrm{~h}$, corresponding to a work capacity and productivity of 56 trees/h and 28 trees/h-worker. Overall net time for processing was $9.15 \mathrm{~h}$ equal to a work capacity and productivity of 28 trees/h and 14 trees/h-worker respectively.

Net additional time, necessary for movements from one tree to the next, was $0.51 \mathrm{~h}$. Unavoidable down time, necessary for worker rest was $1.01 \mathrm{~h}$, while accidental down time, as a result of refuelling the chainsaw and sharpening the blade was $0.76 \mathrm{~h}$.

Gross work time was thus $16 \mathrm{~h}$ which corresponds to a work productivity of $1.77 \mathrm{~m}^{3} / \mathrm{h}$-worker. Net time used for felling and processing was equal to $29 \%$ and $56 \%$ respectively of the total time.

Moreover, figure 2 shows how transfer times (NAT) accounted for 3\%, rest time 7\% (UDT) and accidental down time (ADT) for 5\%. Net time to carry out bunching, which concerned only the B2 test area, was $1.70 \mathrm{~h}$ while net additional time were equal to

\begin{tabular}{|c|c|c|c|c|c|}
\hline \multicolumn{2}{|c|}{$\begin{array}{l}N T \\
{[h]}\end{array}$} & \multirow{2}{*}{$\begin{array}{r}N A T \\
{[h]}\end{array}$} & \multirow{2}{*}{$\begin{array}{c}U D T \\
{[h]}\end{array}$} & \multirow{2}{*}{$\begin{array}{c}A D T \\
{[h]}\end{array}$} & \multirow{2}{*}{$\begin{array}{l}G T \\
{[h]}\end{array}$} \\
\hline Felling & Processing & & & & \\
\hline 4.57 & 9.15 & 0.51 & 1.01 & 0.76 & 16 \\
\hline
\end{tabular}

Note: $\mathrm{NT}=$ net work time, NAT $=$ net additional time,

UDT $=$ unavoidable down time, ADT $=$ accidental down

time, GT = gross work time

TABLE 4 - Analysis of felling and processing times. 


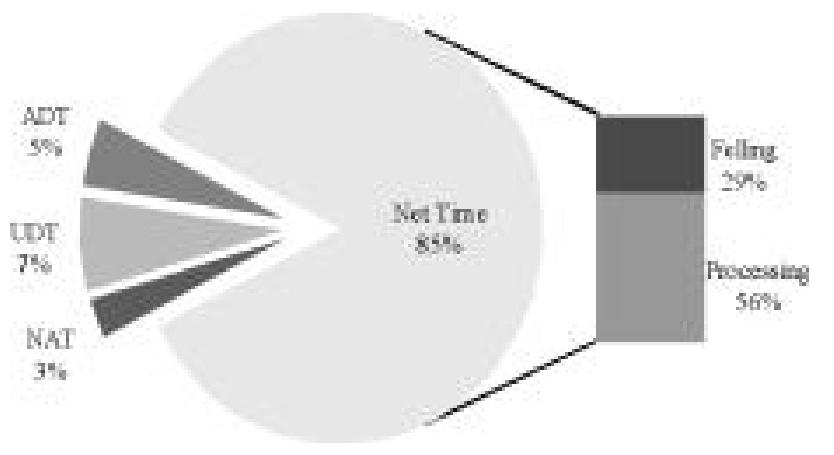

Fig. 2 - Percentage division of felling and processing times.

$0.31 \mathrm{~h}$; down time (DT) for worker rest took up 3.75 $\mathrm{h}$. The total amount of sliding wood on steep terrain, net of conversion losses, was $11 \mathrm{~m}^{3}$; total gross time was therefore $5.76 \mathrm{~h}$, which corresponds to a work productivity of $0.95 \mathrm{~m}^{3} / \mathrm{h}$-worker.

With regard to the logging of trunks by tracked tractor, total time in block A was $2.35 \mathrm{~h}$ for material destined for paper mills and $2.42 \mathrm{~h}$ for that destined for packing (table 5) with a total volume of $20.4 \mathrm{~m}^{3}$.

To complete loading, hauling and unloading at the paper mill material landing took 6 trips along the extraction track, with a work productivity of 2.14 $\mathrm{m}^{3} / \mathrm{h}$-worker.

For material destined for the production of packing 7 trips were necessary with a work productivity of $2.20 \mathrm{~m}^{3} / \mathrm{h}$-worker.

In block B total hauling time, which regarded a total volume of $15 \mathrm{~m}^{3}$, was $2.13 \mathrm{~h}$ for paper mill materi$\mathrm{al}$ and $1.62 \mathrm{~h}$ for packing material (table 6 ).

Four trips are required to complete the hauling of paper mill material with a work productivity of 1.15 $\mathrm{m}^{3} / \mathrm{h}$-worker.

Instead for packing material 5 trips are needed for a work productivity of $1.64 \mathrm{~m}^{3} / \mathrm{h}$-worker.

Hauling therefore required a total time of $8.42 \mathrm{~h}$, of which $52 \%$ of the time involved loading and $29 \%$ for transport and unloading at the landing (figure 3 ).

\begin{tabular}{l|cc|cc}
\hline \multicolumn{5}{c}{$\begin{array}{c}\text { WORK TIME } \\
{[\mathrm{h}]}\end{array}$} \\
\hline \multicolumn{1}{c}{ Block } & \multicolumn{3}{c}{ A } & \multicolumn{2}{c}{ B } \\
\hline \multirow{3}{*}{ Loading } & Paper mill & Packing & Paper mill & Packing \\
Extraction & 1.38 & 1.15 & 0.98 & 0.88 \\
Unloading & 0.49 & 0.53 & 0.35 & 0.45 \\
Down Time & 0.21 & 0.20 & 0.17 & 0.06 \\
Total & 0.17 & 0.54 & 0.63 & 0.23 \\
& $\mathbf{2 . 2 5}$ & $\mathbf{2 . 4 2}$ & $\mathbf{2 . 1 3}$ & $\mathbf{1 . 6 2}$ \\
\hline
\end{tabular}

TABLE 5 - Work times for hauling operations.

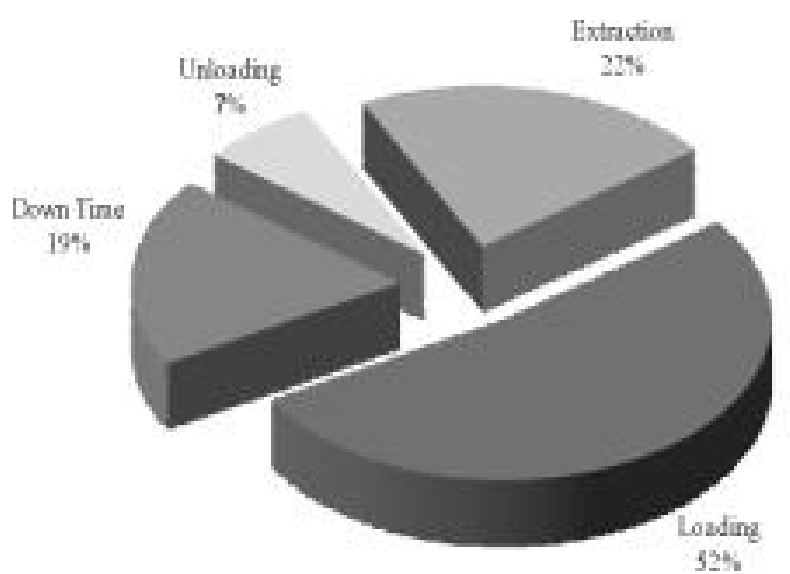

Fig. 3 - Percentage distribution of total hauling times.

Table 6, which refers to the work team, shows the times for the chipping operation. The total time taken for $3,500 \mathrm{~kg}$ of converted branchwood was $16.8 \mathrm{~h}$ corresponding to a work production of $104 \mathrm{~kg} / \mathrm{h}$ worker.

The net time for chipping was $13.02 \mathrm{~h}$; additional time necessary for moving the chipper and changing sacks totalled $0.68 \mathrm{~h}$, while down time took up $3.10 \mathrm{~h}$.

Chipping therefore takes up $78 \%$ of the total time, additional net time accounts for $4 \%$, while down time makes up the remaining $18 \%$ (figure 4).

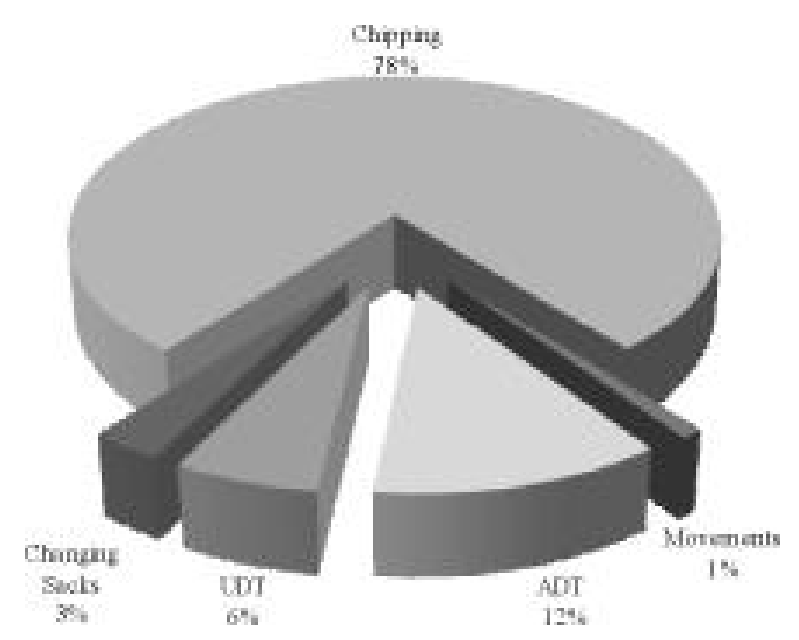

Fig. 4 - Percentage division of chipping times.

\begin{tabular}{ccccc}
\hline Movement & Chipping & $\begin{array}{c}\text { Sack } \\
\text { changing } \\
{[h]}\end{array}$ & UDT & ADT \\
{$[h]$} & {$[h]$} & {$[h]$} \\
\hline 0.18 & 13.02 & 0.50 & 1.02 & 2.08
\end{tabular}

Note: UDT $=$ unavoidable down time, ADT $=$ accidental down time.

TABLE 6 - Specific times of chipping operation. 


\begin{tabular}{l|c|c}
\hline \multicolumn{3}{c}{ WORK TIME } \\
{$[\mathrm{h}]$}
\end{tabular}

TABLE 7 - Distribution of work times for loading and transportation of chipped material.

The final phase, which concluded the operation, involved transporting the sacks of chipping out of the forest and loading them onto a lorry.

Table 7 illustrates the distribution of specific times for this operation.

Total work time was $2.9 \mathrm{~h}$, with a work productivity of $402 \mathrm{~kg} / \mathrm{h}$-worker.

Analysis of the data shows substantial homogeneity among the partial times required for this operation and those taken for the extraction of ligneous material. This is due to the fact that the machinery and extraction tracks were the same as those used previously.

Mean productivity in relation to the felling, processing and extraction phases was $1.64 \mathrm{~m}^{3} / \mathrm{h}$-worker, while for conversion and transportation of the ligneous cull material the figure was $253 \mathrm{~kg} / \mathrm{h}$-worker.

\section{Risults and considerations on silvicultural aspects}

It is well known that the populations studied were not adequately managed and the absence of appropriate tendings has inevitably led such artificial systems to a state of acute precariousness, considering the increased vulnerability of artificial formations of this species compared to natural ones, with regard to meteorological and parasitical dangers. Elaborations and subsequent studies by Mercurio (in press), conducted in the same experimental plots, provide a valid contribution towards understanding whether thinning can lead to a significant "revival" of natural evolutive processes guaranteeing such populations a greater degree of stability, complexity and environmental value, in other word their "renaturalization" $[12,13]$.

These studies, although referring to an experimental period of only two years, appear to confirm how the application of these treatments, are able to guarantee the recovery of the system's functional efficiency.

In particular (table 8), it was found that heavy thinning, thesis $\mathrm{B}$, triggered dynamic processes in the population, given the greater diametric increment and basal area ascertained, able to guarantee greater resist-

\begin{tabular}{|c|c|c|c|c|c|c|c|}
\hline \multirow{2}{*}{ Thesis } & & \multicolumn{2}{|c|}{ Block A } & \multicolumn{2}{|c|}{ Block B } & \multicolumn{2}{|c|}{ TOTAL } \\
\hline & & Ic & $\boldsymbol{G r}$ & Ic & $G r$ & $I c$ & $G r$ \\
\hline \multirow{4}{*}{$T$} & $D m$ & 0.7 & 2.9 & 0.4 & 1.6 & 1.1 & 4.5 \\
\hline & $h m$ & 0.3 & 3.7 & 0.1 & 1.5 & 0.4 & 5.2 \\
\hline & $G$ & 0.5 & 2.3 & 1.0 & 1.4 & 1.5 & 3.7 \\
\hline & V & 23.4 & 3.2 & 1.9 & 0.2 & 25.2 & 3.4 \\
\hline \multirow{4}{*}{$\boldsymbol{A}$} & $D m$ & 0.8 & 2.8 & 0.7 & 2.4 & 1.4 & 5.2 \\
\hline & $h m$ & 0.3 & 1.5 & 0.2 & 0.9 & 0.4 & 2.4 \\
\hline & $G$ & 1.7 & 2.5 & 2.0 & 3.6 & 3.7 & 6.1 \\
\hline & $V$ & 18.8 & 2.9 & 9.5 & 1.6 & 28.3 & 4.5 \\
\hline \multirow{4}{*}{$B$} & $D m$ & 1.3 & 4.4 & 0.4 & 1.3 & 1.7 & 5.7 \\
\hline & $h m$ & 0.5 & 2.4 & 0.2 & 0.9 & 0.7 & 3.3 \\
\hline & $G$ & 1.5 & 2.8 & 2.5 & 5.1 & 4.0 & 7.9 \\
\hline & $V$ & 25.0 & 4.9 & 10.5 & 2.1 & 35.5 & 7.0 \\
\hline \multirow{4}{*}{ TOTAL } & $d m$ & 2.7 & 10.1 & 1.4 & 5.3 & 4.2 & 15.4 \\
\hline & $h m$ & 1.0 & 7.6 & 0.4 & 3.3 & 1.4 & 10.9 \\
\hline & $G$ & 3.7 & 7.6 & 5.5 & 10.1 & 9.2 & 17.7 \\
\hline & V & 67.1 & 11 & 21.9 & 3.9 & 89.0 & 14.9 \\
\hline
\end{tabular}

Note: $\mathrm{Dm}=$ mean diameter $[\mathrm{cm}], \mathrm{hm}=$ mean height $[\mathrm{m}]$, $\mathrm{G}=$ basal area $\left[\mathrm{m}^{2}\right], \mathrm{V}=$ volume $\left[\mathrm{m}^{3}\right], \mathrm{Ic}=$ current annual increment, $\mathrm{Gr}=$ growth rate [\%].

TABLE 8 - Current annual increment and growth rate.

ance to physical and biological adversities, predisposing it to the renewing.

\section{Conclusions}

In view of the need for a re-evaluation of the cited reforestations by means of specific tendings, such as thinning, able to cause a significant ecological and structural "revival" of forest systems, the present work notes that the level of mechanization adopted in the experimentation, despite being of an initial type, produced more than satisfactory technical and silvicultural results which merit more detailed subsequent investigation, also in light of comparison with the encouraging results obtained with data present in literature on work productivity $[1,3,5,14,16,17]$.

Thus, in light of the experience carried out, a number of useful indications can be drawn with regard to the operations observed in the forest.

For felling and processing it emerged how it is possible to improve performance by eliminating, or at least reducing, the amount of unproductive time. A wellmaintained chainsaw and greater attention in executing cutting technique, could indeed contribute towards reducing down time caused by jamming of the machinery. Moreover, more careful organization of the work could lead to a reduction in the time needed to move workers and machinery from one tree to the next.

It appears difficult, in this phase, to introduce a mechanization based on combined operator machinery like harvesters and forwarders. Such difficulties are attributable to the habitat characteristics of forests, ownership structure and typology of forestry enterprises. However, it needs to be noted that the availability of both light harvesters adapted for thin- 
ning and machinery half way between the above and those for clear cutting, available over a longer period and in more difficult operating conditions, which could represent an interesting alternative to conversion techniques used in Calabria $[16,18]$.

A larger degree of mechanization in bunching operations, carried out for free sliding, could doubtless contribute towards increasing work productivity. The use of forest winches, yarders and the use of small, easily manoeuvrable and highly versatile machinery such as All Terrain Vehicles (A.T.V.) [15] are examples of possible alternatives.

For extraction, a better distribution of secondary tracks would lead to a reduction in loading times, allowing a larger number of trips during the working day resulting in an increase in productivity. The use of mini-skidders and specialized forest tractors characterized by a high level of mobility and equipped also to be used in other phases is also desirable with the objective of guaranteeing a general increase in the efficiency of the entire chain.

Finally, with regard to the chipping operation, we point out that the machine used cannot be considered suitable for the kind of foreseen intervention because of its technical peculiarities and its limited power. Indeed big branches have caused continuous blocks in the grinding room. An interesting innovating process, applicable only after evaluating the efficiency of specific chippers for forest jobs, could be represented by the densification [5]. The process is carried out by machines able to compress the branchwood into shapes similar to logs, thus permitting the use of nonspecialised machinery for handling and transportation operations, such as forest trailers and lorries equipped with hydraulic cranes, with an increase in the carrying capacity of the machinery used.

The mechanical innovations identified, supported by a suitable management policy, based on the re-naturalization of artificial populations, would allow in Calabria, if well modulated, a lowering in costs, a reduction in exertion and hardship for workers, resulting in the bringing about of an optimal exploitation of the forest, in safeguarding its use [18].

\section{References}

[1] Baldini S., Picchio R., Gallo P., Produttività, sicurezza e qualità. Fattori a confronto nell'utilizzazione di una fustaia, Sherwood, (2006), 123, 41-47.

[2] Berti S., Piegai F., Verani S., Manuale d'istruzione per il rilievo dei tempi di lavoro e delle produttività nei lavori forestali, Quaderni dell'Istituto di Assestamento e Tecnologia Forestale, (1989), Fascicolo IV, Firenze.

[3] Calafatello A.R., Catania P., Vallone M., PiPITONE F., Analisi tecnica di cantieri meccanizzati nelle operazioni di utilizzazioni forestali in Sicilia., Rivista di Ingegneria Agraria, (2005), 3, 55-59.

[4] Castellani C., Scrinzi G., Tabacchi G., Tosi V., Inventario forestale nazionale italiano. Tavole di $\mathrm{Cu}$ - batura doppia entrata, Ministero dell'Agricoltura e delle Foreste, Istituto Sperimentale per l'Assestamento Forestale e per l'Alpicoltura, (1994), Trento, 37-38.

[5] Cavalli R., Linee innovative nella meccanizzazione forestale. La situazione dell'arco alpino, Sherwood, (2002), 81, 5-11.

[6] Ciancio O., Mercurio R., Nocentini S., Le specie forestali esotiche nella selvicoltura italiana, Ann. Ist. Sper. Selv., (1981-82), Arezzo, Vol. XII-XIII.

[7] Ciancio O., Diradamenti: criteri generali, problemi e tecniche, Monti e Boschi, (1986), 6, 19-22.

[8] Ciancio O., Nuove frontiere nella gestione forestale, Accademia Italiana di Scienze Forestali, (1999), Firenze, 349 pp.

[9] Hippoliti G., Piegai F., Tecniche e sistemi di lavoro per la raccolta del legno, (2000), Compagnia delle Foreste, Arezzo, 157 pp.

[10] Iovino F., Menguzzato G., Ipotesi di gestione della realtà forestale della Calabria, Atti della giornata preparatoria al secondo Congresso nazionale di selvicoltura "Il ruolo del bosco nello sviluppo sociale ed economico della Calabria”, Crotone, (1998), 117-124.

[11] La Marca O., Elementi di dendrometria, (1999), $1^{\text {a }}$ edizione, Patron editore, Bologna., 512 pp.

[12] Mercurio R., La rinaturalizzazione dei rimboschimenti mediante l'applicazione del taglio a buche (stato dell'arte della ricerca), Atti del Convegno "Il ruolo della meccanizzazione per il rilancio della selvicoltura in Calabria”, Reggio Calabria, (2002), 143-150.

[13] Nocentini S., La rinaturalizzazione dei sistemi forestali: aspetti concettuali, L'Italia Forestale e Montana, (2000), 55 (4), 211-218.

[14] Monarca D., Paris P.G., Picchio R., La meccanizzazione dei cantieri forestali: esperienze nel centro Italia, Atti del Convegno "Il ruolo della meccanizzazione per il rilancio della selvicoltura in Calabria", Reggio Calabria, (2002), 35-46.

[15] Picchio R., Savelli S., Di Fulvio F., Sviluppi nei lavori forestali di ATV e minitrattori, Alberi e Territorio, (2005), 10-11, 26-30.

[16] Spinelli R., Nati C., Magagnotti N., Il diradamento meccanizzato delle piantagioni da legno. Prove comparative a Montecchio Precalcino (VI), Sherwood, (2005), 110, 33-39.

[17] Verani S., Produttività e costi dell'utilizzazione di boschi cedui e piantagioni di conifere, Monti e Boschi, (1995), 6, 18-22.

[18] Zimbalatti G., Bonfà D., Giametta F., Prospettive di meccanizzazione delle utilizzazioni forestali in Calabria, Atti del Convegno "Il ruolo della meccanizzazione per il rilancio della selvicoltura in Calabria”, Reggio Calabria, (2002), 57-66.

\section{SUMMARY}

Artificial reforestation of Corsican pine, carried out in Calabria in the 1950s and 1960s lacked the essential management phase following planting with the result that they are now in a precarious state of physical and biological balance. 
Therefore, given the present situation, it is necessary to intervene with a policy of rational management, based on re-naturalization, in order to best restore the structural and functional balance. Of the different tendings, thinning has a fundamental role in promoting such evolutive processes.

The research, conducted in Aspromonte, examines a chain of forestry utilization engaged in selective thinning from below, carried out with varying intensities of intervention in order to assess their capacity and productivity.
The results of the research show how, despite the low level of mechanization used, work productivity falls fully within the national average, and how these too often discontinued silvicultural operations instead prove to be fundamental in encouraging the growth in the efficiency of Calabrian forest systems.

Key words: Thinning, re-naturalization, Corsican pine, work analysis. 
